\title{
Corruption Impede Access to Public Health Services in Benin
}

\author{
Denis Acclassato Houensou, Fidel Saliga \\ Department of Economic, University of Abomey, Calavi, Cotonou, Benin
}

Email address:

saligdel@yahoo.fr (F. Saliga)

To cite this article:

Denis Acclassato Houensou, Fidel Saliga. Corruption Impede Access to Public Health Services in Benin. International Journal of Health Economics and Policy. Vol. 4, No. 3, 2019, pp. 73-81. doi: 10.11648/j.hep.20190403.12

Received: May 21, 2019; Accepted: June 29, 2019; Published: September 2, 2019

\begin{abstract}
Health care is one of the indispensable factors contributing to the improvement of productivity and the welfare of human capital. Indeed, most developed countries focus on improving the health status of populations. Despite significant improvements in the health status of human capital, there are disparities in equal access to health care. This finding is fundamentally linked to the structuring, organization and functioning of public hospitals in developing countries. The purpose of this article is to analyze the effect of corruption behavior on access to health care in public hospitals in Benin. The methodological approach adopted in this work explains the probability, for a user in contact with the health services of public hospitals, of developing corrupt behaviors [1,2]. The estimation of selection model, based on survey data from users of public hospitals in Benin, shows that corruption behavior facilitates access to health care for applicant. But taking collectively, they slow down the normal functioning of health care services, create a congestion effect and increase the vulnerability of users of public health hospitals. In addition, the estimation results reveal a negative and significant effect between drug diversion and corrupt behavior on the one hand and the fact of not having social security coverage decreases the probability of developing corruption behaviors other. The study recommends, on the one hand, the establishment of surveillance mechanisms for public hospital actors and, on the other hand, an increase in penalties for corrupt behavior.
\end{abstract}

Keywords: Access to Healthcare Services, Institutions, Corruption Behavior, Congestion Effect Selection Model

\section{Introduction}

The public health hospital is an open place for health applicant and the only access to health care services [3]. The health sector has become one of the pockets of corruption [4]. Corruption behavior in the health sector is a global problem, and its magnitude is significant in both rich and developing countries $[5,6]$. Corruption is an illegal agreement for which which the agent demands or accepts bribes in exchange for privileged access [7]. Indeed, it results from the failure of institutions [8]. Institutions are the rules of game, the norms established to regulate behavior and reduce transaction costs [9]. In the presence of weak institutions, corruption appears as an alternative to circumvent established rules. The defenders of the positive view of corruption analyze corruption as a compensating factor for institutional dysfunction $[10,11]$. Corruption is like oil that facilitates economic transactions [10]. Corruption has long been presented as an element to compensate for the poor functioning of institutions. Thus, the work on corruption leads to the fact that, by improving efficiency, corruption would have positive effects on economic activity $[10,11]$. Corruption makes it possible to overcome the rigidities imposed by governments that hinder investment and interfere with other economic decisions favorable to growth [2].

This idea, which supports the positive effect of corruption, is countered by authors who point out that corruption behavior leads to the inefficiency of the health system. Some authors dispute this view by defending the principle of bilateral responsibility among the actors of the health system $[12,13]$. Corruption appears as a crime where responsibilities are shared between the corrupted user and the corrupt practitioner. Since access difficulties are usually the result of a rigid and inefficient bureaucracy, it is beneficial to stimulate it to gain speed and productivity [14]. Many authors have argued that corruption increases the costs of public services $[15,16]$. These hidden economic costs are difficult to observe $[17,18]$. Authors show that corruption 
has negative effects on the development of the health sector [19-22]. These negative effects are related not only to barriers for users to access to health care services [23], but also to their relatively low incomes, imbalances between health centers in urban and rural areas [24]. Inequalities in access to health care services are also related to the fact that public health centers do not have enough resources to cover the needs of health care seekers [25]. Corruption happens to be a roundabout way to access health care services. Authors shows that corruption harms the delivery of health services and has negative consequences for the development of the health sector [22, 26-28]. Corruption does not favor the use of public health facilities and has a direct negative impact on the access of the relatively poor population through informal payments [20, 27, 29]. Informal payments for medical services often discourage relatively poor users from consulting [30,31]. Corruption has a direct negative effect on the quality of medical care [32], it causes inefficiency in health care and filters access to health benefits. It leads to a decline in the use of health services, an increase in waiting times and the deterioration of the well-being of users [26].

In Benin, only $54 \%$ of the rural population has access to health facilities over a radius of five kilometers, and the health infrastructure coverage rate is $88.3 \%$ in 2011 compared to $93.1 \%$ in 2016 ; the attendance rate of public health services rose from $29.7 \%$ in 2015 to $25.9 \%$ in 2016 [33. 34]. Healthcare costs borne by patients represent barriers to access to health care benefits [35]. Households account for $42.2 \%$ of health expenditure, which limits their access to health care [36]. Health spending ranges from $2.58 \%$ of GDP in 1995 to $2.34 \%$ of GDP in 2015 [37], and more than half of the population does not have access to essential medicines [36]. Users develop corrupt behaviors when trying to access public services in their country and about $22 \%$ of public service users have paid a bribe [38]. In Africa, relatively poor using public services have likely paid twice a bribe than the rich users. What are the effects of corrupt behavior on access to health care benefits? The purpose of this paper is to analyze the effect of corruption behavior on access to health care services in public health centers in Benin. The contribution of this paper is twofold, it aims to show, on the one hand, that corruption behavior negatively affects the income of relatively poor households and on the other hand limits their access to health care benefits in public health centers.

The rest of the paper is organized as follows. The second section deals with the literature review on corruption related to inequalities of access. The third section discusses the methodology of the study and the last discusses the specification of the model and the presentation of the estimation results.

\section{Literature Review}

This literature review exposes corrupt behaviors and agency relationships, incentive mechanisms to corrupt behavior and corrupt behavior in public hospitals.

\subsection{Corruption Behaviors and Agency Relationship}

From the 1970 s, the principal-agent model is mobilized to analyze the state structures that are conducive to the development of corruption. Corruption is rooted in the delegation system which is a mechanism for coordination and facilitation of transactions within public health centers. The corruption arises from the externality imposed on the briber by the relationship of delegation, against and even beyond the will of the principal, in the absence of a contractual relationship between the principal and the briber. Corruption draws its specificities from the interweaving of two contracts with divergent objectives.

The resulting corruption problems include inappropriate ordering of tests and procedures that increase rents and financial gains, bribes for health care, absenteeism, and misappropriation of public resources for private purposes [39].

However, the information is asymmetric between different actors, making it difficult to identify and control diverging interests [40]. The behavior of these different actors creates risks of corruption and conflicts of interest [41, 42], and inadequate regulation in the health sector [43]. The delegation system within public health centers creates incentives for the development of corrupt behavior.

\subsection{Incentive Mechanisms for Corrupt Behavior}

The economic literature discusses the incentives theory to explain the corruption behavior of economic stakeholder [21, 44-46]. The incentive theory suggests that corruption depends on the aversion to the illegality of the briber and the public official. It announces that corruption behavior increases if the expected rent is high and that the corruption is all the more extended as the expected profit is high. However, the corruption decreases with the increase of the salaries in public sector [2]. Incentive theory shows that there is an efficiency wage comparable to the expectation of bribery that can prevent corruption behavior. As instrument, this incentive is intended to reconcile the divergent interests of the delegate and delegate through the provisions established by the delegation contract [47]. This relationship between the salary of health professionals and the level of corruption is not significant. The risks of corruption in the health sector are only influenced by several organizational factors [48]. Stakeholders attending the public health industry are often unaware of their rights. In addition, there is a wide variety of dispersed actors in the health sector, decision makers, health care providers, health professionals and consumers who interact in complex ways. These are interactions between patients and health professionals, between payers and hospitals and between hospitals and providers [19].

\subsection{Corruption Behaviors in Public Hospitals}

The economic literature has focused on the different relationships between actors mainly from the public sphere [12]. The public sphere is characterized by relationships that 
are totally hierarchical where the superiors dictate, without any difficulty, their orders to inferiors.

However, bureaucrats modify orders and substitute for the realization of public interests that of their own private interests. These behaviors flout pre-established norms and rules and undermine the principles of the new institutional economy that specifies the set of rules and norms that delimit and regulate the behavior of individuals [49]. Corruption is breaks down as the monopoly plus discretion less responsibility [50]. In fact, the monopoly creates opportunities for corruption and limits users' ability to choose other service providers. If the government is the only provider of medical services, the patient may be forced to pay bribes to access these services. Discretion refers to the autonomous power of a public official to make decisions such as hiring staff or deciding what medications are needed and in what quantities to procure them. Practitioners use discretion to authorize and accredit health facilities, providers, services and products, opening up risk and abuse of power in the use of resources [48]. Clinical care providers also exercise their discretion in making decisions about the amount and types of services a user should have.

The head of health services may choose to hire an unqualified parent, or a procurement officer. He may decide to purchase a new, high-priced drug in amounts that go well beyond what is needed to obtain a promised bribe. Transaction transparency allows corruptors to more easily identify the officer in charge of discretion [51]. The lack of accountability refers to the behaviors of practitioners who work in the underfunded and inefficient public sector with limited promotions and little supervision. However, those in high-paying jobs in the private sector are encouraged to generate business for their employers by overvaluing and over-treating patients, both medically and financially [52].

\section{Methodology}

We present in this section the econometric model, the specification of the empirical model and the data collection technique.

\subsection{Econometric Model}

The econometric model used explains the likelihood that a user in contact with public health centers will develop corrupt behavior $[1,2]$. We study the probability that a user will develop corruption behaviors during his / her visit to public health services to access health care. Let $\mathrm{y}$ be the variable capturing the corruption behavior of user $i$ and $\mathrm{y}^{*}$ the unobservable variable measuring the degree of user involvement in corruption. The analysis model can be written in the following form:

$$
y=\left\{\begin{array}{ccc}
1 & \text { si } & y^{*}=\sum \beta_{i} x_{i}+\varepsilon_{i} \\
& 0 & \text { otherwise }
\end{array}\right.
$$

With $x_{i}$ denoting of the user's characteristics, $\beta_{i}$ the associated parameter and $\varepsilon_{i}$ the error term that is assumed to follow the normal distribution.
The user in contact with the public health center assigns a level of utility to each of his corruption behavior and selects the one that provides the maximum utility.

This model postulates that the utility of choice has a probabilistic nature. This randomness does not call into question the deterministic nature of individual choices but reflects the idea that only a part of the determinants of choices is observable.

In fact, on the one hand, individual preferences are influenced by a set of unobservable characteristics specific to users, and on the other hand, certain characteristics of the goods involved in decision-making may escape an external evaluator. Thus, this utility is broken down into systematic utility and the other random. Formally, the utility function is written:

$$
U_{i}=V_{i}+\varepsilon_{i}
$$

With $U_{i}$ the utility of the user $i$ for the choice of the corruption behavior in the set of alternatives; $V_{i}$, the systematic component of utility and, $\varepsilon_{i}$ the error term. The rational user adopts the corruption behavior that maximizes its utility among all the alternatives of the $C_{n}$ choices, namely:

$$
y_{i}=f\left(U_{i}\right)=\left\{\begin{array}{rrr}
1 & \text { si } & U_{i} \text { est } \max _{i} U . \\
& 0 & \text { sinon } .
\end{array}\right.
$$

With $y_{i}$ a choice indicator equal to 1 if alternative $i$ is chosen, 0 otherwise. Starting from (2), the corruption behavior i will be chosen from the set of choice alternatives $C_{n}$ if and only if:

$$
\begin{gathered}
U_{j}>U_{i}, \forall j \neq i \in C_{n} \\
V_{j}+\varepsilon_{j}>V_{i}+\varepsilon_{i} \text { and } V_{j}-V_{i}>\varepsilon_{i}-\varepsilon_{j}
\end{gathered}
$$

Since the value of the inequality is unobservable, we must look at the probability of occurrence of corruption behavior. The probability of choosing the alternative $i$ from among all the possibilities of the set $C_{n}$ is thus expressed [53].

$$
\begin{gathered}
P_{i}=P_{r}\left(y_{i}=\frac{1}{C_{n}}\right) \\
P_{i}=P_{r}\left(U_{j}>U_{i}\right), \forall j \neq i \in C_{n} \\
P_{i}=P_{r}\left(V_{j}-V_{i}>\varepsilon_{i}-\varepsilon_{j}\right), \forall j \neq i \in C_{n} \\
\log \left[\frac{p_{i}}{1-p_{i}}\right]=X_{i}^{\prime} \beta
\end{gathered}
$$

Since the distribution of $\varepsilon_{i}-\varepsilon_{j}$ is not known in the analysis, we must make assumptions about the nature of its distribution. In discrete choice models, random terms are traditionally assumed independently and identically distributed (idd) according to an extreme value distribution [54].

The probit model served as a framework for identifying the profile of users who develop corruption behaviors to access health care services. But, probit regression for dichotomous variables ignores selection bias problems. 
Consequently, the two-step method is an alternative for correcting these possible selection biases [55]. The selection equation reflects the propensity to opt for corrupt behaviors to access health care. It is formalized as follows:

$$
\begin{gathered}
y_{1 i}= \begin{cases}1 & \text { si } y_{1 i}^{*}>0 \\
0 & \text { si } y_{1 i}^{*} \leq 0\end{cases} \\
y_{1 i}^{*}=X_{i} \beta+\varepsilon_{i}
\end{gathered}
$$

$y_{1 i}^{*}$ is a latent variable that presents the decision to corrupt the user in contact with the public health center. The substantial equation is written as follows:

$$
\begin{gathered}
y_{2 i}= \begin{cases}1 & \text { si } y_{2 i}^{*}>0 \\
0 & \text { si } y_{2 i}^{*} \leq 0\end{cases} \\
y_{2 i}^{*}=W_{i} \alpha+\gamma_{i}
\end{gathered}
$$

With $y_{2 i}^{*}$ the latent variable which represents the access to health care services of the corrupt user, with $\mathrm{W}_{\mathrm{i}}$ and $\mathrm{X}_{i}$ the observable socio-demographic variables; $\gamma_{i}$ following a normal distribution $N(0,1)$ and $\varepsilon_{i}$ a normal distribution $N\left(0, \sigma_{\varepsilon}\right)$ and $\rho$ the correlation coefficient of the error terms.

\subsection{Specification of the Empirical Model}

In this section, we present the model to be estimated, the different variables and their sources. Following equation [7], the model is presented as follows:

$$
X_{i}^{\prime} \beta=\beta_{0}+\beta_{1} X_{1 \mathrm{i}}+\beta_{2} \mathrm{X}_{2 \mathrm{i}}+\beta_{3} \mathrm{X}_{3 \mathrm{i}}+\cdots+\beta_{\mathrm{k}} \mathrm{X}_{\mathrm{ki}}+\epsilon_{i}
$$

With $X_{i}^{\prime}$ denoting the variables of the study and $\beta_{i}$ the parameters to be estimated. The variable of interest is a binary variable that denotes the corruption behavior of the public health centers users. It takes the value 1 if the user develops the corruption behaviors and 0 otherwise.

The explanatory variables concern sociodemographic and economic factors that can lead to corruption behavior at the level of the public health centers users. These include indicators such as gender, education, income, participation in the health care market; and the share of income spent on health care [2].

\subsection{Data Collection Techniques}

The data used come from the TraSCoB project database built from the results of surveys conducted at public hospitals in Benin. The data were collected on a sample of 1652 users of public health centers. This survey was conducted among users of the HKM National University Hospital Center (Hubert Koutoukou Maga), Departmental University Hospital Center Ouémé-Plateau (CHUD-OP) and the University Hospital Center of Abomey-Calavi and Sô-Ava and the University Hospital Center-Mel. Based on simple random sampling formula [56]. The sample size is determined as follows:

$$
n_{i}=\frac{N_{i}(u-\alpha / 2)^{2} P_{i}\left(1-P_{i}\right)}{\left(N_{i}-1\right) d^{2}+(u-\alpha / 2)^{2} P_{i}\left(1-P_{i}\right)}
$$

With $\mathrm{i}=(1,2,3,4)$ the index which represents the public health centers, with $p$ the proportion of the population that frequents each public center of health and which is supposed to develop behaviors of corruption $(u-\alpha / 2)=1,96$ the difference which corresponds to a degree of confidence of $95 \%, \mathrm{u}-\alpha / 2$ is the fractile of order $1-\alpha / 2$ of the reduced normal centered law $\mathrm{N}(0,1)$; $\mathrm{d}$ the risk threshold $(5 \%)$ and $\mathrm{N}$ the estimated population size of the health zone.

Table 1. Summary of user size.

\begin{tabular}{lllll}
\hline public hospitals & Health Zone & Attendance Rate & Size & Size (with margin of error) \\
\hline CNHU-HKM & 235731 & $42.44 \%$ & 375 & 420 \\
CHU-Mel & 139220 & $39.91 \%$ & 368 & 412 \\
CHUD-OP & 545258 & 44.97 & 380 & 426 \\
CHUD-Cal & 774462 & $35.00 \%$ & 350 & 392 \\
Summary & & & 1473 & 1650 \\
\hline
\end{tabular}

Thus, $\mathrm{n}=1473$ users and to compensate for non-response or other cases, we added $12 \%$ of this number and we could obtain an approximate size $\mathrm{N}=1475 *(1.12)=1652$ users

\begin{tabular}{|c|c|c|c|c|c|}
\hline Variables modalities & Mean/\% & St. Dev. & Obs & Low & Max. \\
\hline \multicolumn{6}{|l|}{ sex (reference: male) } \\
\hline $\begin{array}{l}\text { female } \\
\text { corruption behavior (reference: no) }\end{array}$ & 64.34 & $(0.479)$ & 1063 & 0 & 1 \\
\hline yes & 13.20 & $(0.338)$ & 218 & 0 & 1 \\
\hline \multicolumn{6}{|c|}{ assessment of health care (reference: unsatisfied) } \\
\hline satisfied & 73.31 & $(0.733)$ & 1211 & 0 & 1 \\
\hline very satisfied & 5.87 & $(0.058)$ & 97 & 0 & 1 \\
\hline once & 24.03 & $(0.427)$ & 397 & 0 & 1 \\
\hline several times & 41.83 & $(0.493)$ & 691 & 0 & 1 \\
\hline
\end{tabular}

instead of $n=1473$. Table 2 below provides a summary of the descriptive statistics analysis of the variables in the model.

\section{Results}

Table 2. Descriptive statistics. 


\begin{tabular}{|c|c|c|c|c|c|}
\hline Variables modalities & Mean/\% & St. Dev. & Obs & Low & Max. \\
\hline monthly income (reference: less than 50000) & & & & & \\
\hline between 50000 and 150000 & 0.375 & $(0.484)$ & 621 & 0 & 1 \\
\hline between 150000 and 300000 & 0.039 & $(0.195)$ & 66 & 0 & 1 \\
\hline between 300000 and 500000 & 0.006 & $(0.081)$ & 11 & 0 & 1 \\
\hline $\begin{array}{l}\text { over } 500,000 \\
\text { social coverage (reference: yes) }\end{array}$ & 0.084 & $(0.278)$ & 140 & 0 & 1 \\
\hline $\begin{array}{l}\text { no } \\
\text { drug diversion (reference: no) }\end{array}$ & 84.02 & $(0.366)$ & 1388 & 0 & 1 \\
\hline $\begin{array}{l}\text { yes } \\
\text { usefulness of care (reference: yes) }\end{array}$ & 84.93 & $(0.357)$ & 1403 & 0 & 1 \\
\hline no & 4.06 & $(0.197)$ & 67 & 0 & 1 \\
\hline
\end{tabular}

From table 1 it results that the standard deviations are small, which means that the variances are minimal between the values of the variables. No need to make a logarithmic transformation to normalize the observations. In terms of the statistical properties of the variables, the possible presence of multi-collinearity which is likely to bias the results was solved according to the correlation test [57], at the end of which all the coefficients obtained are weak and less than 0.7. The estimation by the probit model does not take into account the selection bias. As a result, two-stage selection model is used to correct a possible selection bias [55].

Table 3. Model selection Heckman.

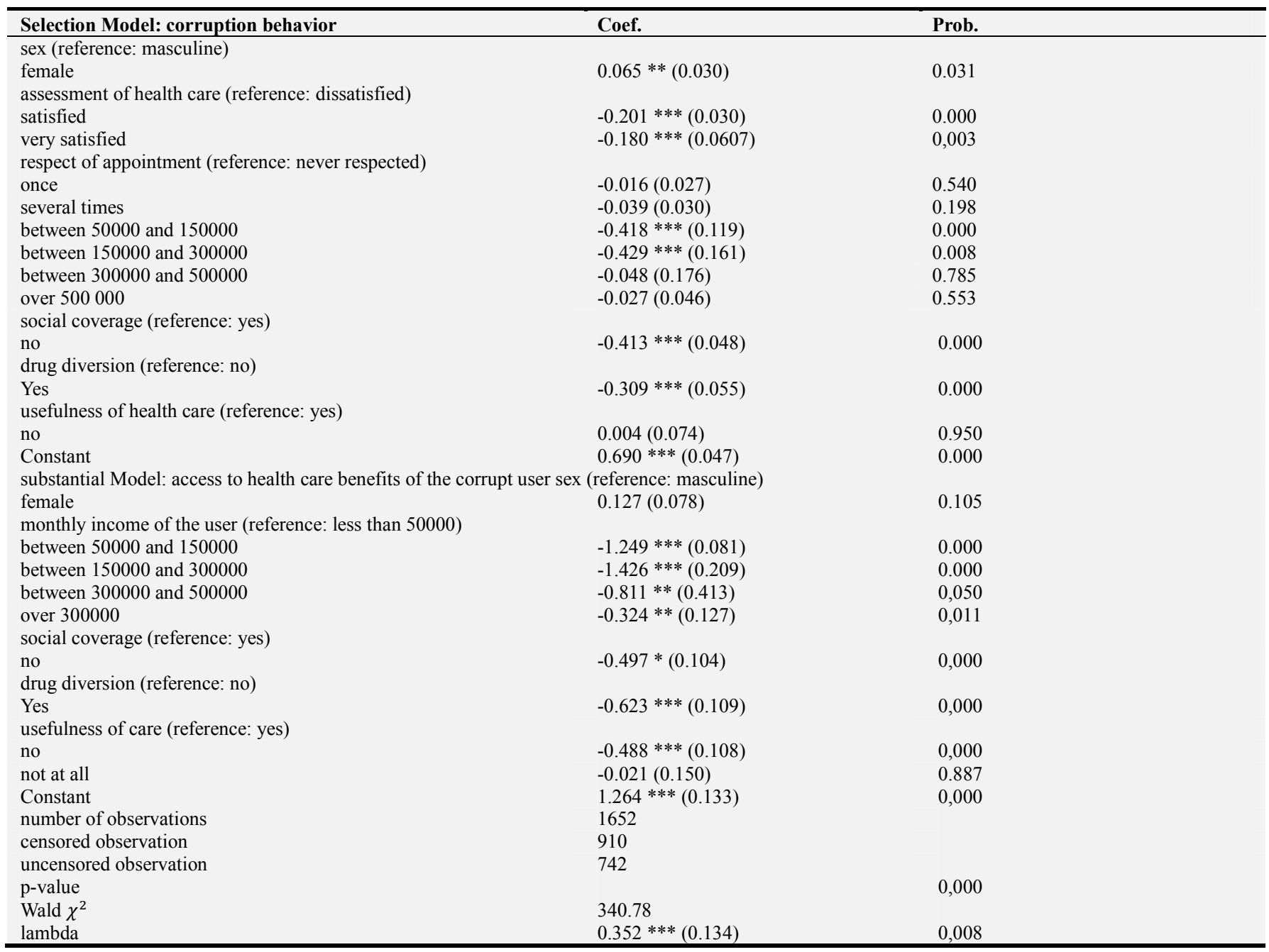

The convergence is rapid since it takes place after six iterations with a Wald statistic of 340.78. In total, the model is well specified with pvalue $=0.000<0.05$ and the hypothesis $\mathrm{H} 0$ that all the coefficients are equal to zero is rejected. Indeed, only the correlation coefficient of the error terms in the two equations captured by lambda, the inverse of the Mill's ratio, is 0.352 . The Chi-square test displays a $(\rho)$ significantly different from $0\left(H_{0}: \rho=0\right)$. The rejection of the null hypothesis (pvalue $<0.05$ ) means that the substantial equation is not independent of the selection equation, in fact the share of income devoted to health care by a user of the public health centers and the option made for corruption 
behavior are not decisions taken independently.

\subsection{Gender and Corruption Behavior}

The estimation of the model by two-step selection method reveals that sex has a positive and significant effect on user corruption behavior. Moreover, being a man increases the probability of developing corruption behavior by 6.5 percentage points compared to female users. If our results reveal that men develop more corrupt behaviors compared to women, this is due to the fact that the man who heads the household takes his family to the hospital, he has the financial decision-making power necessary to offer the services. Bribes to be quickly taken care of women, on the other hand, are mostly household keeper and, given their domestic production activities, are unable to mobilize a high income to bribe and are able to spend more time at hospital. This justifies the hypothesis that the user's gender participates in the choice of corruption behavior in public health centers. In light of previous findings, women are less tolerant of corruption [58]. However, it is worth noting that other results show that it is not the presence and participation of women that reduce corruption, but rather the effectiveness of institutions [59].

\subsection{Monthly Income and Users Corruption Behavior}

The results show that monthly incomes of the user negatively and significantly explains their corruption behaviors in the selection model and in the substantial model. Users with relatively low monthly incomes find it difficult to develop corrupt behaviors, as opposed to users with relatively high incomes. The relatively low-income health care claimant cannot even cover all the expenses related to the renewal of his health stock and therefore they cannot mobilize an additional amount to bribe. On the other hand, users of relatively high-income hospitals manage to release an excess amount for bribery after having borne their health expenses. This result is explained by the fact that users who have the ultimate goal of renewing their health stock and belong to a relatively low income bracket replace a portion of their monthly income that should be spent on health care in bribery. The income of these users does not allow them to simultaneously offer bribes and purchase drugs. This result is justified by the fact that corruption reduces the net income of the poor [38]. Corruption leads to additional costs for the public sector, including over-billing of health services, and the income disparity is positively correlated with corruption [60]. Also, corruption generates the unequal distribution of resources and affects the income of the community [61]. Similarly, income is correlated negatively with corruption and in a statistically significant way $[62,63]$. The following are the reasons for claiming bribes: gender, income, education, marital status, and the state of institutions in the country, the wealth of an individual [58].

\subsection{Users Appreciation and Corruption Behavior}

The estimation results reveal a negative and significant link between user appreciation and its corruption behavior. When the requesting health care agent is not satisfied with the care provided in the public center, he does not hesitate to offer a bribe to ensure better care and care better quality of health unlike the user who is satisfied. Health care claimants who are satisfied with health care benefits no longer have to bribe, but hospital users who are dissatisfied with the provision of health care are the obligation to offer a bribe in return for a health service that meets its expectations. This analysis is in line with the conclusions which state that users are sensitive to the effort deployed by the practitioner and when this effort does not make it possible to restore their health stock, they opt for corrupt behavior in order to have a satisfaction [64, 65]. These results are in line with the theoretical predictions that corruption behavior in public health centers reflects problems of transparency, mainly difficulties related to the functioning of the health care market $[66,67]$. From this point of view, corruption is indeed a diversion of the ends of an institution with a view to a personal advantage or more generally of a private gain, whether personal or collective [68, 69].

\subsection{Diversion of Drugs and Users Corruption Behavior}

The estimated coefficient of the drug diversion variable is negative and significant in the substantial model and the selection model. Users who are reluctant to develop corrupt behavior in public health centers are subject to a long list of medicines to finance, these drugs are not necessarily intended for use but will be diverted and sold at a low cost than that of the formal market compared to health-seeking users who are predisposed to giving bribes do not register the misuse of their medications. This process consists in prescribing drugs to dying users and who will be diversed by a group of people that tolerates corruption. This is in line with our expectations since the diversion of drugs is a signal that reflects the presence of corruption behavior. The diversion of drugs in public clinics and their resale on the private market justifies the existence of corruption [70]. These corruption behaviors result in the existence of a parallel market for the sale of medicines, at a price lower than that of the formal market, whose source comes from the diversion of medicines from users who had not previously given payoff and who pay in return for the loss of their medicines. Thus, all prescribed medications that lengthen the prescription were prescribed with the intention of being diverted later. These results are in line with assessments that fraud and corruption in its various forms can result in the disappearance of as much as $25 \%$ of the drugs purchased [71]. This result reflects the fact that users who are victims of crimes such as drug theft are more in contact with a corrupt public administration [2, 72].

The lack of diagnostic equipment, the theft of medicines, the absenteeism of the professionals, the lack of rigor and method, the lack of punctuality, the non-respect of the meetings of the users contributed to discredit this sector with statistics catastrophic [73]. In addition, the increase in drug diversion limits access to health care benefits for health care seekers. Once the drugs bought by the user are diverted and 
he has no income to renew his purchase. He no longer has the opportunity to access health care. Users with precarious economic and financial powers do not have access to quality healthcare services [74].

\subsection{Social Security and Corruption Behavior}

The estimated coefficient for the variable (social coverage) is negative and significant in the selection model and in the substantial equation. When health care applicants have social coverage, they do not develop corrupt behavior. Since the public center user who has social coverage does not directly pay for his health care and in most cases the members of this household who benefit from this coverage can go to the health center without necessarily having a health insurance sum to corrupt. Most users who have social security coverage do not necessarily have the means to fully support their health expenditure and therefore they do not have the possibility to offer bribes, which contributes to the reduction of health care behaviors corruption in public health centers. On the other hand, other types of users who, in addition to social security and in complicity with health care providers, overcharge the costs of providing health care either by prescribing a long list of useless drugs that will be resold on a parallel market diversion of drugs. The income obtained in this illegal transaction is transferred to all the members of the collusion who tolerates corruption, which justifies corruption behavior in the health sector. The causes of corruption would be due to the opportunistic behavior of rational agents who would coordinate on the market of corruption [75]. Indeed, users who have the ultimate goal of renewing their health stock and this through their social coverage do not opt for corrupt behavior. This result is explained by the fact that social coverage facilitates access to care in public health centers and reduces corruption behavior. In addition, users with social coverage in public administration contacts access health care because social insurance works as a guarantee of access to health care benefits and the health care user is no longer bribe, which helps to reduce his corrupt behavior. This result confirms that access to health care benefits is conditional on income and there is a correlation between type of health coverage and access to health care benefits [76]. In the light of theoretical work, the type of health financing influences the level of corruption [40]. That a system relying on funding from a social security institution is more exposed to corruption so that medical staff prescribe unnecessary medical care or that the public authority subsidizes acts that have never been carried out [5].

\section{Conclusion}

In sum, unequal access to health care services is linked to the fact that public health centers are particularly vulnerable to corruption [4], and they do not have enough resources to cover the needs of health claimants [25]. The objective of this research is to analyze the effect of corruption behaviors on access to health care services in public health centers in Benin. The estimation of selection model [55], based on survey data from users of public health centers in Benin in 2017, showed that corruption behavior facilitates access to health care services for each health care applicant. But collectively, they slow down the normal functioning of health care services, create a congestion effect and increase the vulnerability of users of public health centers. Users of public health centers may have to commit acts of corruption for three main reasons: firstly, the opportunity to commit such behavior allows them to quickly access health care. Second, individual values, social norms and the erosion of public service values can contribute to creating an environment in which corruption appears to be justified, and thirdly, inadequate wages can put some pressure on public servants, who will give up therefore to corruption [30]. The fight against corruption will then have to continue in order to clean up the health care market so that its operation becomes more efficient.

\section{References}

[1] Akerlof G., 1970, The market for lemons: qualitative uncertainly and market mechanism, Quaterly Journal of Economics, 74, pp. 488-500.

[2] Amnudsen I., Andvig J. Chr., Fjeldstad O. H., 2000, Research on corruption-A Policy oriented survey, CMI, Commissioned Sudies Norad.

[3] Arrow K. J., 1963, Uncertainty and the welfare economic of medical care, American Economics Rreview, 53 (5), pp. 941973.

[4] ASS, 2012, Annuaire des Statistiques Sanitaires, Ministère de la santé, République du Bénin.

[5] ASS, 2017, Annuaire des Statistiques Sanitaires, Ministère de la santé, République du Bénin.

[6] Azfar O., Gurgur T., 2004, Crime, crime reporting and governance, Mimeo, IRIS University of Maryland, College Park.

[7] Bac C., Cornilleau G., 2001, Comparaison international des dépenses de santé: une analyse des évolutions dans sept pays depuis 1970, Dossiers Solidarité-Santé, n¹, pp. 79-88.

[8] Banfield E. C., 1975, Corruption as a Feature of Governmental Organization, Journal of Law and Economics, 18 (3), pp. 587-605.

[9] Bardhan P., 1997, Corruption and Development: A Review of Issues, Journal of Economic Literature, 35 (3), pp. 1320-1346.

[10] Becker G. S., 1968, Crime and Punishment: An Economic Approach, Journal of Political Economy, 76 (2), pp. 169-217.

[11] Bien F., 2001, Essai en économie de la santé et assurance, Thèse de doctorat en sciences économiques. Université Paris $\mathrm{X}$ Nanterre.

[12] Cadot O., 1987, Corruption as a gamble, Journal of Public Economics, 33 (2), pp. 223-244.

[13] Cartier-Bresson J., 2008, Ecomonie politique de la corruption et de la gouvernance, Paris, L'Harmattan, Coll. Ethique économique. 
[14] Cheung A., Hernandez-Julian R., 2006, Gender and corruption: a panel data analysis, Available at SSRN.

[15] Cockcroft L., 2014, Global corruption: Money, power and Ethics in the ModernWorld, Cape Town: BestRed, HSRC imprint.

[16] Damania R., Fredriksson P. G., List J. A., (2004), Trade liberalization, corruption; and environmental policy formation: theory and evidence, Journal of Environmental Economics and Management, 46 (3), pp. 490-512.

[17] Delavallade C., 2006, Corruption and distribution of public spending in developing countries, Journal of Economics and Finance, 30 (2), pp. 222-239.

[18] Di Tella R., Savedoff W. D., 2001, Shining light in dark corners, In DiTella R., and Savedoff W. D., (ed), Diagnostic corruption, Washington, DC: Inter-American Development Bank.

[19] Dor A., Watson H., 1995, The hospital-physician interaction in U.S. Hospitals: Evolving payment schemes and their incentives, European Economic Review, 39 (3-4), pp. 795803.

[20] Doumbouya M. L., 2008, Accessibilité des services des services de santé en Afrique de l'Ouest: le cas de la Guinée, Working Paper, halshs-00229696.

[21] Dourgnon P., Jusot F., Fantin R., 2012, Payer peut nuire à votre santé: une étude de l'impact du renoncement financier aux soins sur l'état de santé, IRDES, Document de travail, $\mathrm{n}^{\circ} 47$.

[22] Dreher A., Herzfeld T., 2005, The Economic costs of Corruption: A Survey and new Evidence, Mimeo.

[23] Ensor T., 2004, Informal payments for health care in transition economies, Social Science and Medecine, 58: 237-46.

[24] Francis K., Edmeston M., 2012, Beyond band-aids: reflection on public and private health care in South Africa, Journal of the Helen Suzman.

[25] Gaitonde R., Oxman A. D., Okebukola P. O., Rada G., 2016, Intervention to reduce corruption in the health sector, Cochrane Database of systematic Reviews, Issue 8. Art. $\mathrm{n}^{\circ}$ : CD008856.

[26] Geeraert J., Rivollier, E., 2014, L'accès aux soins des personnes en situation de précarité; Soins, Elsevier Mason, pp. 14-18.

[27] Giezendanner F. D., 2012, Taille d'un échantillon aléatoire et marge d'erreur, Instruction Publique, Culture et Sport, Service Ecole-Médias, Genève, pp. 7.

[28] Graeff P., Mehlkop G., 2003, The impacts of economics freedom on corruption: different patterns for rich and poor countries, European Journal of Political Economy, 19, 605620 .

[29] Greene W. H., 2005, Econométrie, Paris: Pearson Education France; $5^{\text {ème }}$ Edition, pp. 943.

[30] Griliches Z., 1994, Productivity, R\&D, and the Data constraint, American Economic Review, vol. 84, Issue 1, 123.

[31] Gupta S., Davoodi H., Tiongson E., 2000, Corruption and the prevision of health care and education services, Document de travail. IMF, WP, pp. 00-116.

[32] Heckman J. J., 1979, Dummy endogenous variables in a simultaneous equation systems, Econometrica, 46 (4), pp. 931-959.

[33] Hunt J., 2006, How corruption hits people when they are down, William Davidson Institute Working Paper, n836.

[34] Jacquemet N., 2005, Microéconomie de la corruption, Revue Française d'Economie XX, (4), pp. 118-159.

[35] Jain A., 2014, Corruption: le secret ouvert de la médecine, $B M J, 348,4184$.

[36] Kassirer J., 2006, The corruption influence of money in Medecine, Rapport Mondiale de Transparency International sur la corruption.

[37] Klitgaard R., 1991, Tropical gangsters, London, IB, Tauris.

[38] Klitgaard R., 1998, Cleaning up and invigorating the civil service, Public Administration and Development, vol. 17, $\mathrm{n}^{\circ} 4$.

[39] Klitgaard R., Mc Lean-Abaroa R., Lindsey Parris H., 2002, Villes corrompues, du diagnostic aux remèdes, Nouveaux Horizons-ARS, Paris.

[40] Latham G. P., 2001, The importance of understanding and changing employe outcome expectancies for gaining commitment to an organizational goal, Full Publication History.

[41] Lavallée E., Razafindrakoto M., Roubaud F., 2008, Les mécanismes à l'origine de la corruption: une analyse sur micro-données africaines, Document de travail Dial.

[42] Lavallée E., Razafindrakoto M., Roubaud F., 2010, Ce qui engendre la corruption: une analyse microéconomique sur données africaines, Revue d'Economie du Développement, vol. 18 , pp. 5-47.

[43] Leff N. H., 1964, Economic development through bureaucratic corruption, American Behavioral Scientist, n'8: $8-14$.

[44] Leonard K., 2009, The cost of imperfect agency in health care: evidence from rural Cameroun, Journal of Developpment Economics, vol. 88 (2), pp. 282-201.

[45] Lewis M., 2006, Govenance and corruption in public health care systems, Working Paper, ${ }^{\circ} 78$, Washington, DC: Center for global development.

[46] Lewis M., 2007, Informal payments and the financing of health care in development and transition countries, Health Affairs, 26: 984-97.

[47] Lewis M., Perttersson G., 2009, Governance in health care delivery: raising performance, World Bank Policy Research Paper. 5074.

[48] Leys C., 1964, What is the problem about corruption, The Journal of Modern African Studies, vol. 3, $\mathrm{n}^{\circ} 2$ : 215-230.

[49] Livinec B., Milleliri J-M., Rey J-L., Saliou P., 2013, Inégalités d'accès aux soins en Afrique. Plaidoyer pour un New Deal, l'exemple scandinave, GISPE, $82 \mathrm{db}$. Tellène, 13007, Marseille, France, www.gispe.org.

[50] Lui F., 1985, An equilibrium queuing model of bribery, Journal of Political Economy, 93: 760-81. 
[51] McFadden D. L., 1974, Conditional Logit analysis of qualitative choice behavior, In Frontiers in Econometrics, Zarembka P. (eds.), New York: Academic Press, pp. 105-42.

[52] Neron P-Y., 2014, A quoi sert la conception institutionnelle de la corruption? Les ateliers de l'Ethique, vol. 9, n¹, pp. 103 125

[53] Newhouse J. P., 1996, Reimbursing health plans and health providers: selection versus efficiency in production, Journal of Economic Literature, 34, pp. 1236-1263.

[54] Nordberg C., Vian T., 2008, Corruption in the health sector, U4 Brief 10, Chr. Michelson Institute, Bergen Norway.

[55] North D. C., 1990, Institutions, institutional change and economic performance. Herzfeld Cambridge, University Press.

[56] OECD, 2015, Health at a glance; OECD indicators, ocde publishing

[57] Paldam M., 2002, The Big Pattern of Corruption: Economics, Culture and the Sceaw Dynamics, European Journal of Political Economy, 18, pp. 215-240.

[58] PNUD, 2011, Lutte contre la corruption dans le secteur de la santé: méthodes, outils et bonnes pratiques, Edition: 2011.

[59] Rapport UE, 2017, Rapport général sur l'activité de l'Union Européenne, Europa UE, édition 2017.

[60] Rispel L. C., De Jager P., Fonn S., 2015, Exploring corruption in the South African health sector, Health Policy and Planning, 31, 239-249.

[61] Rose-Akerman S., 1999, Corruption and government: Causes, consequences, and reform; Cambridge: Cambridge University Press.

[62] Rose-Ackerman S., 2004, The challenge of poor governance and corruption, Copenhagen Consensus Challenge Paper, www.copenhagenconsensus.com.

[63] Savedoff W. D., 2006, The causes of corruption in the health sector: a focus on health care systems, In: Transparency International, Global Report.
[64] Scott J., 1972, Comparative Political Corruption, Englewood Cliffs, NJ: Prentice Hall.

[65] Spearman C., 1904, Géneral intelligence, objectively determined and measured, American Journal of Psychology, 15: 201-293.

[66] Szende A., Culyer A. J., 2006, The inequity of informal payments for health care: the case of Hungary, Health Policy, 75 (3).

[67] T. I., 2015, Classement 2015: les pays les plus corrompus, Global corruption report 2015. London: Pluto Press.

[68] T. I., 2016, How corruption in your country, corruption perception index, Global Corruption Report, Berlin: T. I.

[69] Venard B., 2013, Institutions, corruption et développement durable, Bulletin d'économie, vol. 33, n²4, pp. 2545-2562.

[70] Vian T., 2007, Review of corruption in the health sector: theory, methods and interventions, Health Policy and Planning; 23: 83-94.

[71] Vian T., 2008, La corruption dans le secteur de la santé, Traduction d'U4 Issue 2008: 7, Anti- Corruption Ressource Centre, www. U4, nºU4 Issue: 14.

[72] WHO, 2009, Analyse de la structure sanitaire.

[73] WHO, 2016-2019, Stratégie de coopération de l'OMS avec le Bénin.

[74] Williamson O. E., 2000, The New Institutional Economics: Taking Stock, Looking Ahead, Journal of Economic Literature, vol. 38, n³, pp. 595-613.

[75] World Bank, 2010, Silencieuse et fatale, la corruption discrète entrave les efforts de développements de l'Afrique, Washington, DC.

[76] World Bank, 2017, Empowering the poor to fight corruption, The World Bank, http://web.worldbank.org/wbsite/external/topics/extpoverty/ex tempowerment $/ 0$. 